\title{
Can Preoperative Factors or Operative Characteristics Predict the Duration of Hospitalization and Rate of Complications after Pulmonary Resections?
}

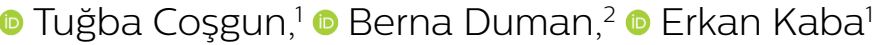

\begin{abstract}
'Department of Thoracic Surgery, Demiroğlu Bilim University Faculty of Medicine, İstanbul, Turkey 2 Department of Chest Disease, Demiroğlu Bilim University Faculty of Medicine, İstanbul, Turkey
\end{abstract}

Submitted: 14.04.2019 Accepted: 04.11.2019

Correspondence: Tuğba Coşgun Demiroğlu Bilim Üniversitesi Tıp Fakültesi, Göğüs Cerrahisi Anabilim Dalı, İstanbul, Turkey E-mail: tugba_cosgun@hotmail.com

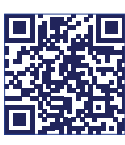

Keywords: Forced expiratory volume; lung resection; mean pulmonary artery pressure.

\begin{abstract}
Objective: Preoperative pulmonary and cardiac function tests and some characteristics of the patients and surgery may predict operative outcomes after resection for lung cancer. In this study, we aimed to analyze the effects of these parameters on short-term outcomes.

Methods: This is a retrospective study, including 117 patients who underwent surgical anatomical resection due to lung cancer and carcinoid tumor at a single center between January 2018 and September 2018. In this study, body mass index, forced expiratory volume in I sec $\left(\mathrm{FEV}_{1}\right)$, transfer coefficient of the lung for carbon monoxide (KCO), ejection fraction, mean pulmonary artery pressure, and neoadjuvant treatment were evaluated and categorized into groups. Logistic regression and Kruskal-Wallis analysis were used to determine the predicted effects of the parameters on the duration of hospitalization and general complication rates. The patients who underwent major chest-wall reconstructions were excluded from this study.
\end{abstract}

Results: The series comprised of 72 males and 45 females, with a mean age of $63.8 \pm 9.8$ years. Most patients underwent a lobectomy $(n=87 ; 61.5 \%)$. The evaluated parameters were not related to the duration of hospitalization and general complication rates. However, neoadjuvant treatment and preoperative low FEVI were significantly related to occurring postoperative pneumonia.

Conclusion: Over the limits of safety, which have been well known, preoperative pulmonary and cardiac functions did not predict the duration of hospitalization in patients who underwent resections for lung cancer. Postoperative pneumonia was related to the neoadjuvant treatment and relatively lower preoperative $\mathrm{FEV}_{1}$. The longer duration of hospital stay was the only parameter related to open surgery.

\section{INTRODUCTION}

Lung cancer is one of the leading causes of cancer-related deaths worldwide, in both developed and developing countries. ${ }^{[l]}$ Assessment of a patient's ability to tolerate anatomic lung resection is not complicated for standard values. However, for the patients who are at a critical level, multifactorial and multidisciplinary evaluation is necessary to select patients for anatomic lung resection. ${ }^{[2]}$ Age, neoadjuvant treatment, and high body mass index (BMI) are considered as the probable risk factors for lung resections. ${ }^{[3-5]}$ The preoperative pulmonary function test of patients undergoing pulmonary resection for lung cancer plays a vital role in determining the operability of a patient. Specifically, forced expira- tory volume in I sec ( $\left.\mathrm{FEV}_{1}\right)$ and diffusion capacity of the lung for carbon monoxide (DLCO) are useful and crucial predictors of postoperative mortality and complications. $[6,7]$ Pulmonary function tests are conducted to obtain $\mathrm{FEV}_{\text {, }}$ and DLCO. Cerfolio et al. ${ }^{[8]}$ found that the transfer coefficient of the lung for carbon monoxide (KCO) test is a more sensitive test of diffusion than DLCOin some cases. $\mathrm{KCO}$ is a preferable test and is calculated as DLCO divided by alveolar volume (VA). ${ }^{[8]}$ Additionally, cardiac parameters, especially pulmonary hypertension, should be risk factors for higher morbidity and mortality. [9] We predicted that these parameters affect the duration of hospital stay as a parameter may of short-term outcomes. 


\section{MATERIALS AND METHODS}

\section{Patient selection}

This study was a retrospective analysis of patients who underwent lung resection for lung cancer between January 2018 and September 2018. The patients who underwent major chest-wall resection\&reconstruction were excluded from this study. A total of 117 patients were analyzed in this study. The variables were analyzed, included age, sex, $\mathrm{BMI}, \mathrm{FEVI}, \mathrm{KCO}$, ejection fraction (EF), mean pulmonary artery pressure(PAP), type of anatomical resection (segmentectomy, lobectomy, pneumonectomy), number of resected segments, and type of surgery (minimally-invasive or open).

This study comprised of 72 males and 45 females with a mean age of $63.8 \pm 9.8$ years (range, 23-8I years). Overall, 67 minimally-invasive resections (Robot-assisted thoracoscopic surgery + Video-assisted Thoracic Surgery) and 60 thoracotomies were performed. The total number of patients who underwent lobectomy, segmentectomy, and pneumonectomy was 80,23 , and 7 , respectively.

\section{Neoadjuvant treatment}

Neoadjuvant treatment was performed on 35 patients (29.9\%). In twenty-three cases, only chemotherapy, in twelve cases, additionally radiotherapy was performed. Immunotherapy was applied to one patient. Indications of neoadjuvant treatment were advanced primary tumor in 21 cases and N2 disease in six cases. The other eight patients underwent neoadjuvant treatments due to other reasons, such as the requirement of postponement of operations due to cardiac or other reasons.

\section{Pulmonary function tests}

Pulmonary function tests were performed at the pulmonary function laboratory of the respiratory department. The minimal investigation consisted of standardized spirometry, which measured FEV, and DLCO and DLCO/ $V A$ with the latter two estimated using the carbon monoxide single-breath technique(Zan Messgerate, nSpire Health 500). The results were expressed as absolute values and as percentages of predicted values.

\section{Cardiac functions}

Preoperative electrocardiography and echocardiography (General Electric, v10.8.I) were routinely performed. Ejection fraction (EF) and systolic pulmonary artery pressure (PAP) were assessed in all cases.

\section{Surgery}

All patients in the series underwent anatomical lung resection, including lobectomy, segmentectomy, and pneumonectomy. Video-assisted thoracoscopic surgery, robotassisted thoracoscopic surgery, and thoracotomy were carried out.

\section{RESULTS}

In the present study, the mean age was $63.8 \pm 9.8$ in our series (range 23-8I). There were no significantly correlation on regression $(p=0.78)$ (Table $I)$.

The study comprised of 72 males and 45 females and their durations of hospitalization were $8.5 \pm 6.8$ days and 7.3 \pm 2.9 days, respectively $(p=0.17)$ (Table 2$)$

In our study, 35 patients underwent preoperative neoadjuvant treatment, 82 patients directly underwent surgery, and their durations of hospitalization were $7.8 \pm 2.7$ days and $8.1 \pm 6.5$ days, respectively $(p=0.4)$.

BMI (body mass index) and preoperative pulmonary function test parameters were studied only in 108 patients because of insufficient data available for the rest. The patients were categorized into three groups according to their BMI: <20 $(n=10), 20-3(n=80),>30(n=18)$, and the corresponding durations of hospitalizations for these groups were $8.2 \pm 3.1,8.3 \pm 6.4$, and $7.3 \pm 3.6$ days $(p=0.7)$.

The mean FEV, value was $2290 \pm 70 \mathrm{ml}$ (range 890-4I70) $\mathrm{FEV}$, and duration of hospitalization was not significantly correlated with regression $(p=0.75)$. Comparison of FEV, values categorized into two groups (<2000 ml; >2000 ml) revealed no significance $(p=0.35)$. Patients were categorized into three groups based on $\mathrm{FEV}_{1} \%$ as follows: $<60 \%$, $60 \%-100 \%$, and $>100 \%$, and it was noted that the duration of hospitalization was comparable between the three groups $(p=0.8)$. No correlation was found between the duration of hospitalization and $\mathrm{KCO}$ and $\mathrm{KCO} \%$ ( $\mathrm{p}=0.5$ and $p=0.3$, respectively).

Cardiac parameters, such as preoperative EF (mean 58.7 \pm 3.7 , range 44-65) and PAP (mean 30.1 \pm 6.7 , range $20-55 \mathrm{mmHg}$ ), showed no correlation with the duration of hospitalization ( $p=0.9$ and $p=0.6$, respectively).

The mean duration of hospitalization was $9.68 \pm 8$ days for thoracotomies and $6.9 \pm 2.3$ days for minimally-invasive techniques $(p=0.02)$. When the patients were classified based on the type of resections they underwent, the duration of hospitalization was $8.8 \pm 5.3$ days for patients who underwent pneumonectomy, $6.7 \pm 2.5$ days for those who

Table I. Regression analysis of the variables predictive of length of stay after pulmonary lobectomy

\begin{tabular}{lc}
\hline Variable & Significance \\
\hline Age & $\mathrm{p}=0.78$ \\
FEV $_{1}$ & $\mathrm{p}=0.7$ \\
$\% \mathrm{FEV}$, & $\mathrm{p}=0.57$ \\
KCO & $\mathrm{p}=0.5$ \\
\%KCO & $\mathrm{p}=0.3$ \\
Body mass index & $\mathrm{p}=0.7$ \\
Ejection fraction & $\mathrm{p}=0.9$ \\
Pulmonary artery pressure & $\mathrm{p}=0.6$ \\
\hline
\end{tabular}

FEV : Forced expiratory volume in one second; KCO: Transfer coefficient of the lung for carbon monoxide. 
Table 2. Comparison of the two or three groups of predictive parameters using the Mann-Whitney $U$ and Kruskal Wallis tests on length of stay in hospital

\begin{tabular}{lccc}
\hline Variable & Numbers & Stay in hospital (days) & Significance \\
\hline Sex (male/female) & $72 / 45$ & $8.5 \pm 6.8 / 7.3 \pm 2.9$ & $\mathrm{P}=0.17$ \\
Neoadjuvant treatment (yes/no) & $35 / 82$ & $8.1 \pm 6.5 / 7.8 \pm 2.7$ & $\mathrm{P}=0.4$ \\
Incision (RATS-VATS/thoracotomy) & $42-25 / 50$ & $7.2 \pm 2.2-6.4 \pm 2.3 / 9.7 \pm 8$ & $\mathrm{P}=0.02$ \\
Type of resection (segmentectomy/lobectomy/pneumonectomy) & $23 / 87 / 7$ & $6.7 \pm 2.5 / 7.7 \pm 2.7 / 8.8 \pm 5$ & $\mathrm{P}=0.17$ \\
\hline RATS: Robot-assisted thoracoscopic surgery; VATS: Video-assisted Thoracoscopic Surgery. & &
\end{tabular}

underwent segmentectomies (with the exclusion of one patient with prolonged duration of hospitalization owing to the cerebrovascular event), and $7.7 \pm 2.7$ days for those who underwent lobectomies $(p=0.17)$.

\section{Complications}

Complication rates were comparable between the two genders $(p=0.4 I)$. Postoperative complications were noted in 23 patients who did not undergo neoadjuvant treatment (28\%) and in II patients who underwent neoadjuvant treatment $(3 \mathrm{I} .4 \%)(p=0.7)$. No correlation was noted between $\mathrm{BMI}$ and complication rate $(\mathrm{p}=0.18)$.

$\mathrm{FEV}_{1}, \mathrm{FEV} \%, \mathrm{KCO}$, and $\mathrm{KCO} \%$ did not significantly affect the complication rates $(p=0.38, p=0.7, p=0.2$, and $p=0.9$, respectively). Although EF showed no effect on complication rates $(p=0.48)$, PAP indicated tendency to be significant $(p=0.07)$. Nevertheless, both of these were not related to atrial fibrillation. Additionally, pulmonary parameters, such as $\mathrm{FEV}_{1}, \mathrm{FEV}_{1} \%, \mathrm{KCO}, \mathrm{KCO} \%, \mathrm{BMI}$, and neoadjuvant treatment, were not correlated with atrial fibrillation $(p=0.8, p=0.8, p=0.2, p=0.6, p=0.9, p=0.57$, respectively).

Pneumonia, another frequent postoperative complication, was found to be correlated with neoadjuvant treatment and preoperative $F E V_{1}(p=0.007$ and $p=0.017$, respectively). However, FEV \%, KCO, KCO\%, EF, and PAP had no significant effect on pneumonia $(p=0.2, p=0.6, p=0.6$, $p=0.6$, and $p=0.1$, respectively).

Prolonged air leak had no correlation with any variable $\left(\mathrm{FEV}_{1}, \mathrm{FEV}\right.$ \%, KCO, KCO\%, EF, PAP; $\mathrm{p}=0.6, \mathrm{p}=0,5, \mathrm{p}=0.8$, $\mathrm{p}=0,8, \mathrm{p}=0.6, \mathrm{p}=0.9$, respectively).

When compared with open surgery minimally-invasive surgery did not provide significant advantage regarding the rate of a total number of complications, AF, pneumonia, or prolonged air leak ( $p=0.8, p=0.7, p=0.4, p=0.4$, respectively).

No correlation was found between the type of resection and the occurrence of complications.

\section{DISCUSSION}

Anatomic lung resections are common surgeries conducted by thoracic surgical departments. The duration of hospital stay after a lobectomy has been previously reported to be approximately one week. ${ }^{[10]}$ Notably, the patient's comorbidities and surgical complications, such as prolonged air leak and incisional pain, are some of the reasons for the prolonged duration of the hospital stay. However, older age, lower preoperative FEV, and lower diffusion capacity that were reported to be correlated with the duration of the hospitalization in previous studies did not exhibit any effect in our study. ${ }^{[10]}$ Certainly, all of our patients are well evaluated and baseline requirements include pulmonary functions as safe levels. In cases that predicted postoperative $\mathrm{FEV}$, or KCO was less than $40 \%$, Vo2max (Maximal oxygen uptake) was measured.

The complications analyzed in our study were prolonged air leak, chylothorax, and pneumothorax, which are encountered most often after thoracic surgery, and the classical complications, such as myocardial infarction, acute respiratory distress syndrome, pneumonia, and atrial fibrillation, which were described by Clavien-Dindo. ${ }^{\left[{ }^{\prime \prime}\right]}$ Additionally, we analyzed prolonged air leak, atrial fibrillation, and pneumonia are the three most common complications in our series.

Morbidity after lobectomy was previously estimated to be $10 \%-50 \%$ previously. ${ }^{[12]}$ Prolonged air leak is one of the most common complications after pulmonary resection, with an incidence of $15 \%-18 \%$. Pneumonia is another complication with an incidence of up to $6 \%$, as reported in some studies. ${ }^{[12]}$ Atrial fibrillation is the most frequent arrhythmia after lung resection with an incidence of $10 \%-40 \%$ for all pulmonary resections and $33 \%$ for lobectomies. ${ }^{[13]}$ Seventeen patients had atrial fibrillation in our one hundred seventeen patients, 14 of them were lobectomy and three of them were segmentectomy. In our series, complication rates were not related to gender, neoadjuvant treatment, $\mathrm{BMI}$, pulmonary function parameters ( $\mathrm{FEV}, \mathrm{KCO})$, and $\mathrm{EF}$. A previous study reported comparable complication rates between patients with pulmonary hypertension and the patients without it. ${ }^{[5]}$ However, in our study, PAP showed a trend toward affecting the complication rates significantly $(p=0.07)$. Nonetheless, atrial fibrillation showed no correlation with either preoperative PAP or other risk factors.

Pneumonia, which is a frequent complication, correlated with neoadjuvant treatment and preoperative FEV, $(p=0.007$ and $p=0.017$, respectively). However, no other predicted risk factors correlated with pneumonia.

Obesity has been estimated as a risk factor for patients undergoing lung resections. However, Tulinský et al. ${ }^{[14]}$ could not demonstrate that obesity causes a significant 
increase in complications. In our series, some patients had a lower BMI. Therefore, we analyzed the patients after categorizing them into three subgroups based on their BM levels: $<20,20-30$, and $>30$. However, we found no significance despite performing regression analyses on $\mathrm{BMI}$, complications, or duration of hospitalization.

Flores et al. ${ }^{[15]}$ demonstrated in 2009 that VATS lobectomy was associated with lesser complications than a thoracotomy for lobectomies. In our study, we found that the type of surgery (minimally-invasive or open) had no significant effect on complication rates probably because of proactive postoperative management of the patients who underwent open surgery. Moreover, the duration of hospitalization was longer for open surgeries than for minimally-invasive surgeries; this results should be probably related to the difficulty in controlling pain after open surgery.

In our study, we determined that the patients who underwent neoadjuvant treatment and had lower FEV, values (evaluated with regression test) had a higher risk of postoperative pneumonia. In addition, high PAP was a risk factor for postoperative complications. However, these parameters did not have a direct effect on the duration of hospitalization, which was noted to be only influenced by open surgery. Consequently, we assert that proactive postoperative management may prevent postoperative complications that may cause the prolonged duration of the hospitalization.

Ethics Committee Approval

Retrospective study.

Peer-review

Internally peer-reviewed.

Authorship Contributions

Concept: T.C., B.D.; Design: T.C., E.K.; Supervision: T.C., E.K.; Fundings: T.C., B.D.; Materials: T.C., B.D.; Data: T.C., E.K.; Analysis: T.C.; Literature search: T.C.; Writing: T.C.; Critical revision: T.C.

Conflict of Interest

None declared.

\section{REFERENCES}

1. Li S, Zhou K, Wang M, Lin R, Fan J, Che G. Degree of pulmonary fissure completeness can predict postoperative cardiopulmonary complications and length of hospital stay in patients undergoing video-as- sisted thoracoscopic lobectomy for early-stage lung cancer. Interact Cardiovasc Thorac Surg 2018;26:25-33. [CrossRef]

2. Towe CW, Wu K, Khil A, Perry Y, Worrell SG, Ho VP, et al. Desaturation during Six-Minute Walk Testing Predicts Major Morbidity Following Anatomic Lung Resection among Patients with COPD. Healthcare (Basel) 2019 23;7:16. [CrossRef]

3. Berry MF, Hanna J, Tong BC, Burfeind WR Jr, Harpole DH, D'Amico TA, et al. Risk factors for morbidity after lobectomy for lung cancer in elderly patients. Ann Thorac Surg 2009;88:1093-9.

4. Evans NR 3rd, Li S, Wright CD, Allen MS, Gaissert HA. The impact of induction therapy on morbidity and operative mortality after resection of primary lung cancer. J Thorac Cardiovasc Surg 2010;139:991-6. [CrossRef]

5. Sepesi B, Gold KA, Correa AM, Heymach JV, Vaporciyan AA, Roszik J, et al. The Influence of Body Mass Index on Overall Survival Following Surgical Resection of Non-Small Cell Lung Cancer.J Thorac Oncol 2017;12:1280-7. [CrossRef]

6. Kim HK, Lee YJ, Han KN, Choi YH. Pulmonary Function Changes Over 1 Year After Lobectomy in Lung Cancer. Respir Care 2016;61:376-82. [CrossRef]

7. Greillier L, Thomas P, Loundou A, Doddoli C, Badier M, Auquier $\mathrm{P}$, et al. Pulmonary function tests as a predictor of quantitative and qualitative outcomes after thoracic surgery for lung cancer. Clin Lung Cancer 2007;8:554-61. [CrossRef]

8. Cerfolio RJ, Bryant AS. Different diffusing capacity of the lung for carbon monoxide as predictors of respiratory morbidity. Ann Thorac Surg 2009;88:405-11. [CrossRef]

9. Wei B, D'Amico T, Samad Z, Hasan R, Berry MF. The impact of pulmonary hypertension on morbidity and mortality following major lung resection. Eur J Cardiothorac Surg. 2014;45:1028-33. [CrossRef]

10. Gagarine A, Urschel JD, Miller JD, Bennett WF, Young JE. Preoperative and intraoperative factors predictive of length of hospital stay after pulmonary lobectomy. Ann Thorac Cardiovasc Surg 2003;9:2225.

11. Dindo D, Demartines N, Clavien PA. Classification of surgical complications: a new proposal with evaluation in a cohort of $6336 \mathrm{pa}$ tients and results of a survey. Ann Surg 2004;240:205-13. [CrossRef]

12. Ziarnik E, Grogan EL. Postlobectomy Early Complications. Thorac Surg Clin 2015;25:355-64. [CrossRef]

13. Roselli EE, Murthy SC, Rice TW, Houghtaling PL, Pierce CD, Karchmer DP, et al. Atrial fibrillation complicating lung cancer resection. J Thorac Cardiovasc Surg 2005;130:438-44. [CrossRef]

14. Tulinský L, Mitták M, Tomášková H, Ostruszka P, Penka I, Ihnát P. Obesity paradox in patients undergoing lung lobectomy - myth or reality? BMC Surg 2018;18:61. [CrossRef]

15. Flores RM, Park BJ, Dycoco J, Aronova A, Hirth Y, Rizk NP, et al. Lobectomy by video-assisted thoracic surgery (VATS) versus thoracotomy for lung cancer. J Thorac Cardiovasc Surg 2009;138:11-8. 


\section{Preoperatif Faktörler veya Operatif Özellikler Akciğer Rezeksiyonları Sonrası Hastanede Yatış Süresini ve Komplikasyon Oranını Öngörür mü?}

Amaç: Akciğer rezeksiyonu uygulanan hastalarda preoperatif pulmoner ve kardiyak fonksiyon testleri ve hastaya ve cerrahiye ait özellikler operasyon sonrası sonuçları etkileyebilmektedir. Biz bu çalışmada bu parametrelerin ameliyat sonrası kısa döneme etkilerini değerlendirmeyi amaçladık.

Gereç ve Yöntem: Bu çalş̧mada, Ocak 20।8-Eylül 2018 tarihleri arasında akciğer kanseri ve karsinoid tümör sebebiyle kliniğimizde rezeksiyon uygulanan 117 hasta geriye dönük olarak değerlendirildi. Vücut kitle indeksi, I. saniyedeki zorlu ekspiratuvar volüm, karbonmonoksit difüzyon testi, ejeksiyon fraksiyonu, ortalama pulmoner arter basıncı ve neoadjuvan tedavi bilgileri değerlendirilip gruplara ayrıldı. Lojistik regresyon ve Kruskal-Wallis analiz hastanede kalış ve ameliyat sonrası komplikasyonlar üzerine etkileri saptamada kullanıldı. Majör göğüs duvarı rezeksiyonu yapılan hastalar çalışmadan dışlandı.

Bulgular: Çalışmaya ortalama yaşı 63.8 \pm 9.8 olan 72 erkek ve 45 kadın alındı. Hastalara sıklıkla lobektomi ameliyatı uygulandı ( $n=87 ; \% 6 \mid .5)$. İncelenen parametreler hastanede yatış süresi ve genel komplikasyon oranlarını etkilemedi. Ancak neoadjuvan tedavi, düşük FEV, değeri, ameliyat sonrası pnömoni sıklı̆̆ ile ilişkili bulundu.

Sonuç: Güvenli sınırlar içinde ameliyat öncesi akciğer ve kalp değerlendirme testleri hastanede yatış süresini öngörememiştir. Pnömoni gelişimi neoadjuvan tedavi ve düşük FEV, değeri ile ilişkili çıkmıştır. Hastanede yatış süresini ise etkilen tek parametre açık cerrahi olmuştur.

Anahtar Sözcükler: Akciğer rezeksiyonu; ortalama pulmoner arter basıncı; zorlu ekspiratuar volüm. 